\title{
The Impact of Bank and Non-Bank Financial Institutions on Local Economic Growth in China
}

\author{
Xiaoqiang Cheng • Hans Degryse
}

Received: 13 February 2009 /Revised: 2 September 2009 / Accepted: 6 October 2009 / Published online: 11 November 2009

(C) The Author(s) 2009. This article is published with open access at Springerlink.com

\begin{abstract}
This paper provides evidence on the relationship between finance and growth in a fast growing country, such as China. Employing data of 27 Chinese provinces over the period 1995-2003, we study whether the financial development of two different types of financial institutions — banks and non-banks — have a (significantly different) impact on local economic growth. Our findings indicate that banking development shows a statistically significant and economically more pronounced impact on local economic growth.
\end{abstract}

Keywords Growth $\cdot$ Financial development $\cdot$ Chinese provinces $\cdot$ Banks

JEL codes $\mathrm{E} 44 \cdot \mathrm{G} 21$

\section{Introduction}

The relation between finance and growth has been long under debate. Although some researchers have argued that finance only reacts to the expectation of growth, there has been overwhelming evidence that financial development plays an important role in promoting

\footnotetext{
X. Cheng

LICOS, Katholieke Universiteit Leuven, Debériotstraat 34, Leuven, Belgium

X. Cheng

Center for Economic Studies, Katholieke Universiteit Leuven, Naamsestraat 69, Leuven, Belgium e-mail: xiaoqiang.cheng@econ.kuleuven.be

X. Cheng

International Center for Financial Research, Lally School of Management, Rensselaer Polytechnic Institute, Troy, NY 12180, USA

H. Degryse $(\bowtie)$

CentER, EBC, TILEC, Tilburg University, P.O. Box 90153, NL-5000 LE Tilburg,

The Netherlands

e-mail: h.degryse@uvt.nl
} 
the growth of developed economies (see e.g. Levine (2004) for a survey). Evidence is rather mixed within developing countries. While finance seems to promote growth in some Latin American countries (Haber (1991, 1997)), researchers disagree on the role played by formal and informal finance in China, one of the most important developing countries in the world. Understanding the finance and growth issue in China is of particular importance. China's case is not unique. Most transition countries, like China, suffer from relatively weak legal and financial systems. Therefore, the Chinese experience could be relevant for other countries with similar growth potential and similar legal and financial systems. In addition, with the increasing globalization of trade and international capital flows, the sustainability of China's growth and the stability of its financial system matter not only for the country itself, but also for the rest of the world.

Recent debate on finance and growth in China boils down to the question on how Chinese firms are financed and monitored. One strand of literature reasons that the Chinese legal system and formal financial sector are too weak to enforce sound governance and thus the law, finance and growth nexus does not hold in China (e.g., Allen et al. (2005) and Boyreau-Debray (2003)). Chinese growth then stems from informal financing channels and institutions. The other strand reasons that formal finance in China contributes to growth, despite the relative weakness of the legal system (e.g. Hasan et al. (2006), Ayyagari et al. (2007), Rousseau and Xiao (2007), or (Demitriades et al. 2008)). ${ }^{1}$ Informal finance serves firms who cannot tap formal finance. However, informal finance cannot serve the needs of the higher end of the market since their monitoring and enforcement mechanisms are insufficiently developed (Ayyagari et al. (2007)). We find that banking development plays an important role in Chinese economic growth. Our evidence taken together with that from other recent papers (e.g. Hasan et al. (2006), Ayyagari et al. (2007), Rousseau and Xiao (2007), and Demetriades et al. (2008)), who also support the role of formal finance in China using different datasets and methods, show that the Allen et al. (2005) conjectures are becoming very much a minority view. Our paper therefore shifts the balance of evidence away from the view that formal finance played little role in financing Chinese economic growth.

We contribute to the debate on formal and informal finance by using China's publicly available macro data, employing a set of new perspectives. First, inspired by the classification in Ayyagari et al. (2007) and Allen et al. (2005), we study the impact of formal and informal finance on growth by exploiting heterogeneity between bank and nonbank financial institutions. Ayyagari et al. (2007) separate bank finance which includes local commercial banks and foreign commercial banks, from informal finance which includes financing from informal sources such as non-bank financial institution. ${ }^{2}$ Allen et al. (2005) also distinguishes financing sources from two groups, bank finance and self fund

\footnotetext{
${ }^{1}$ Employing a province-level dataset for the period 1985-1998, Li and Liu (2001) find that growth of provincial aggregate output is positively related to the growth of the loans of the largest banking institutions and self raised funds. They attribute the positive correlation to the improvement in the efficiency of capital reallocation during the liberalization in both financial and real sectors. Hasan et al. (2006), analyze the issue from a broader view. Using panel data covering 31 Chinese provinces for the period 1986-2002, they find that aside from legal environment, awareness of property rights and political pluralism, the development of financial markets are also associated with stronger growth. Guariglia and Poncet (2007) find that only the market driven part of formal financing leads to growth. Ayyagari et al. (2007) are among the first to study finance and growth in China using micro-level data. Employing the World Bank 2003 survey data covering 2400 firms, they find that despite its weaknesses, financing from the formal financial system is associated with faster firm growth, whereas fund raising from alternative channels is not.

${ }^{2}$ In particular, Ayyagari et al. (2007) refer to informal finance as "the entire gamut of non-market institutions such as credit cooperatives, moneylenders, informal credit and insurance, rotating savings and credit associations, etc. that do not rely on formal contractual obligations enforced through a codified legal system."
} 
raising, that includes all other sources such as retained earnings, informal sources, loans from family and friends, trade credit, investment funds, equity and the other category. In either way of classification, these two studies include the non-bank financial institutions as part of informal finance and thus argue that non-bank financial institutions are clearly different from formal sectors. ${ }^{3}$ However, unlike their counterparts that are informal under common law, non-bank financial institutions under China's law actually operate more as contractual arrangements. Moreover, like formal financial institutions such as banks, nonbank financial institutions are also supervised by the Chinese central bank. These facts suggest that though Chinese non-bank financial institutions may belong to informal finance, they actually have characteristics from the formal sector and are in this respect comparable to banks. The uniqueness of China's non-bank financial institutions therefore allows our study of the heterogeneity between those two types of financial institutions to gain further insights on whether the formal or the informal financial sector leads to growth in China, helping to shed light on the difference in results between Allen et al. (2005) and Ayyagari et al. (2007).

Clearly distinguishing non-bank financial institutions from banks in our study has several other merits. First, we add to previous studies employing macro data often consider only banks, as they dominate the Chinese financial sector. Non-bank financial institutions such as rural and urban credit cooperatives, trust and investment companies, and financial companies have been installed as reactions to developments in the formal banking system (see e.g. Laurenceson and Chai (2003), and Kumar et al. (1997)). Second, while crosscountry differences, such as political and cultural variations as well as heterogeneity in accounting standards, make it difficult to directly compare Chinese banks with their international counterparts, China's non-bank financial institutions can serve as a more appropriate "reference group". For identifying the causality between finance and growth, it will be ideal if the difference between banks and non-bank financial institutions only lies in the reforms they have received. Therefore, under the assumption that better reforms lead to greater efficiency, the testable hypothesis will be that the financial development of institutions having benefited more from reforms exhibits greater correlation with growth. Nonetheless, banks and non-bank financial institutions are also different in some other aspects. For instance, while banks have received much earlier and more profound financial reforms but have granted loans mostly to large and medium sized firms in China, non-bank financial institutions have seldom benefited from reforms but have mainly extended their loans to small or private firms. Such differences, however, are working in favor of identifying the causality between finance and growth. Empirically bank development being more correlated with economic growth than the development of non-bank financial sector may indicate the importance of the link between financial reforms and financial

\footnotetext{
${ }^{3}$ Rural and urban credit cooperatives belong to informal finance as Ayyagari et al. (2007) clearly define. Trust and investment companies in China are close to informal banks in Ayyagari et al. (2007)'s definition of informal finance for two reasons. First, they were set up to conduct forms of business prohibited to the formal banks in China, such as that of a financial fiduciary. Their activities on the lending side are essentially the same as a bank. Second, although trust and investment companies in China are subject to contractual enforcement and are called 'companies', not all are formally incorporated under China's Companies Law. The scope of operation of China's trust and investment companies is ill-defined, whilst institutional responsibility for promulgation as well as enforcement remains fragmented. This has led to uncertainty for both regulators and trust and investment companies, and accounts to a large extent for the high level of noncompliance (Kumar et al. (1997)). Financial companies in China normally belong to large enterprises. They do not take deposits but provide financial services such as extending loans for clients or other subsidiaries of their parent enterprises' (Xie (1998)). In this sense, financial companies in China are close to rotating savings and credit associations in Ayyagari et al. (2007)'s definition of informal finance.
} 
development and thus economic growth. Otherwise financial development may simply react to the real sector, given the fact that small and private firms are the engine of China's growth.

In China, most non-bank financial institutions only operate within a province. While banks, especially state-owned banks, have their national-level headquarters, cross-province bank lending seldom happens due to the restriction imposed by the central bank of China. Therefore it is safe for us to compare the performance of those two types of financial institutions at provincial level. Financial development of those financial institutions in each province is measured, in a conventional way, by the ratios of local savings and loans to GDP. The panel dataset we employ covers the period 1995-2003, right after the mid-1990s financial reforms took place. Choosing such a period also helps us alleviating the reverse impact from growth to financial reforms. For instance, the concern that financial reforms were initiated exactly at the time that the economy was expected to boom should then be less of a concern. The growth rates have shown a decreasing trend during our sample period, as the Chinese government has managed to "soft land" the economy since the mid1990s.

Our results show that a clear difference exists between the impact of financial development of banks and non-bank financial institutions on growth. While having extended most of their loans to the large and medium sized firms, banks contribute significantly to local growth. This effect is more pronounced in provinces with foreign entry. As a comparison, non-bank financial institutions, while granting most of their loans to smaller firms in China, seem to be not important for local growth. Such results are robust across different specifications controlling for omitted variables or reverse causality. We attribute this difference to the fact that banks, relative to non-bank financial institutions, have benefited much more from the Chinese ongoing financial reforms. In particular, the reforms include commercialization of state-owned banks, market entry deregulation, and liberalization of interest rates. Our results suggest that, despite the relatively weak Chinese financial sector, at margin banks played an important role in the allocation of funds, and in turn spurred growth. Our finding sharpens the insights of Allen et al. (2005) on the one hand, and Ayyagari et al. (2007), Demetriades et al. (2008), and Rousseau and Xiao (2007), on the other hand, which mainly argue that only the informal and formal financial sector drive growth, respectively.

There is a large literature investigating the link between financial development and growth. ${ }^{4}$ Recent empirical evidence employing cross-country datasets show that finance is positively correlated with growth (see e.g. King and Levine (1993a) or Levine and Zervos (1998)). While the initial cross-country studies may suffer from simultaneity bias, the more recent studies focus on finding proper instruments to extract the exogenous part of financial development when trying to deal with the issue of causality (see e.g. La Porta et al. (1998), Levine et al. (2000) or Demirgüç-Kunt and Maksimovic (1998)) ${ }^{5}$. Another way to avoid cross-country differences that may plague identification is to focus on one country only. Jayaratne and Strahan (1996) for example tackle endogeneity by keeping effects other than

\footnotetext{
${ }^{4}$ Theoretical efforts at modeling growth and financial development include Greenwood and Jovanovic (1990), Boyd and Smith (1992), King and Levine (1993b), and Acemoglu and Zillibotti (1997), to mention just a few.

${ }^{5}$ La Porta et al. (1998) link the legal origin of a country to its financial development. Based upon the above legal origin-finance instruments and using cross-country datasets, a substantial body of empirical work further shows that financial development promotes economic growth in aggregate, industry and firm level analysis (see e.g. Levine et al. (2000) or Demirgüç-Kunt and Maksimovic (1998)).
} 
financial development constant. They use financial deregulation in the early 1970s in a set of U.S.-states as an exogenous shock to local financial development. They find that in the 30 years after the deregulation, the economy grew faster in the deregulated states than in the other states. Guiso et al. (2004) study the effects of differences in local financial development on economic activity in Italy. They find that local financial development enhances the probability that an individual starts a business, increases industrial competition, and in turn spurs firm growth. We contribute to this line of research by focusing on one country and studying different channels of finance that were exposed differently to financial reforms.

The remainder of the paper is organized as follows. Section 2 describes the reforms and the development of the Chinese financial system motivating our empirical framework. Section 3 presents our empirical framework as well as the data. Section 4 discusses the results on the effects of financial development on economic growth. The last Section concludes.

\section{Financial reforms and financial development in china: bank and non-bank financial institutions}

In this section, we show that the financial reforms have mainly affected banks and not the non-bank financial institutions. We discuss this as it helps us in establishing the causal link between banking development and growth in our empirical analysis. Banks and non-bank financial institutions are the two main types of financial institutions in China. Stock markets are also a part of the Chinese financial system, but are less important. ${ }^{6}$ Financial development in China has been heavily shaped by series of financial reforms initiated by the Chinese government during the past decade. Most of the reforms have focused on the banking sector, especially on the state-owned banks, and not on the non-bank financial institutions ( $\mathrm{Li}$ (2001)). We discuss the link between the efficiency of financial institutions and reforms from three aspects: commercialization, market entry deregulation, and liberalization.

\subsection{Commercialization}

Before 1994, the four state-owned banks ${ }^{7}$ were dominating the whole banking sector. In 1994, three policy banks were created to undertake policy lending previously assigned to the four state-owned banks. The latter then became the state-owned commercial banks (SOCBs hereinafter) for commercial financial business only. At the same time, a series of financial reforms have been carried out in order to improve the internal management and risk-control of the SOCBs, and to delink them from their non-banking arms (Li (2001)). In 1998, the Chinese central bank (the People's Bank of China (PBOC hereinafter), allowed

\footnotetext{
${ }^{6}$ For example, at the end of 1994 , the ratio of the stock market capitalization to total assets of financial institutions was approximately $6.7 \%$. Although the importance of stock markets has increased somewhat since the early $1990 \mathrm{~s}$, the scale and the importance of the financing channels of the stock markets are not comparable to those of financial institutions (Allen et al. (2005)). In this paper, we employ a fixed effects panel model incorporating time dummy variables that should deal with any omitted time varying impact of stock markets.

${ }^{7}$ The four state-owned banks are the Bank of China (BOC), the Agricultural Bank of China (ABC), the China Construction Bank (CCB), and the Industrial \& Commercial Bank of China (ICBC).
} 
the SOCBs to make their own lending decisions on a commercial basis. In contrast, the non-bank financial sector has received few reforms. These have been deterred since there is no consensus on the ownership and functions of the non-bank financial institutions, especially of the rural credit cooperatives (RCCs hereinafter) (He (2006) and Xie (1998)). The development of legislation for the trust and investment companies (TICs hereinafter) lags behind that of banks. While the Trust Law didn't enact till the end of 2001, the Commercial Banking Law enacted already in 1995 providing a legal framework for standardizing the operations of the commercial banks.

Figure 1 presents an overview of China's financial institutions at the end of 1994, right after the commercialization. The banking sector entails three policy banks and fifteen commercial banks, of which the four SOCBs are by far the most important in terms of assets. One should notice that each state-owned bank has a large number of branches in almost every city in China. Among the eleven joint stock banks, Bank of Communications (BoCom) is the largest with China's finance ministry its main shareholder. Researchers often refer to the four SOCBs and BoCom as "the five biggest state-owned banks". The non-bank financial sector consists of urban credit cooperatives (UCCs hereinafter), RCCs, TICs, financial companies (FCs), and other institutions. There are many UCCs and RCCs in China, but they are isolated from each other and do not have country-wide headquarters as banks. In sum, bank and non-bank financial institutions are the only two types of financial institutions in China, according to the Almanac of China's Finance and Banking.

Commercialization has several effects. First, the SOCBs gradually reduced their exposure to the state-owned sector, as the proportion of loans to the state-owned sector decreased from $82.4 \%$ in 1994 towards $64.4 \%$ in 2002. Over the period 1994-2002, the short-term loans extended to the non-state-owned sector grew faster, especially stemming from SOCBs, suggesting that the SOCBs were making greater efforts to support the nonstate-owned sector than non-bank financial institutions. ${ }^{8}$ Second, SOCBs had been able to attract high quality personnel, which are crucial to select and monitor projects.

The evolution of non-performing loans (NPLs hereinafter) of SOCBs and non-bank financial institutions illustrates that commercialization improved the efficiency of lending. Table 1 shows that the NPL ratio in the banking sector had been continuously decreasing between 2000 and 2003. Next to the fact that the Chinese government has injected capital to SOCBs, most of the NPLs were actually due to the policy lending during the pre-reform period and little had been newly generated after commercialization (Zhang (2003a, b) and $\mathrm{Xu}$ (2005)). The few available data on the NPL ratio of non-bank financial institutions suggest that this ratio was much higher (50\%) and possibly at an increasing trend (see Table 1).

\subsection{Market entry deregulation}

China has made an effort to stimulate competition among the SOCBs and also to introduce competition from other banks with different ownership structures. In 1986 and 1996, the first joint stock commercial bank (Bank of Communication) and the first private joint stock commercial bank (China Minsheng Banking Corp., LTD. (CMBC)) were created, respectively. Moreover, foreign financial institutions were allowed to setup representative offices in China in 1981. Foreign banks were allowed to setup branches in most important

\footnotetext{
${ }^{8}$ Own computations based on data from the China Credit Yearbook, the Almanac of Finance and Banking in China and Bankscope.
} 


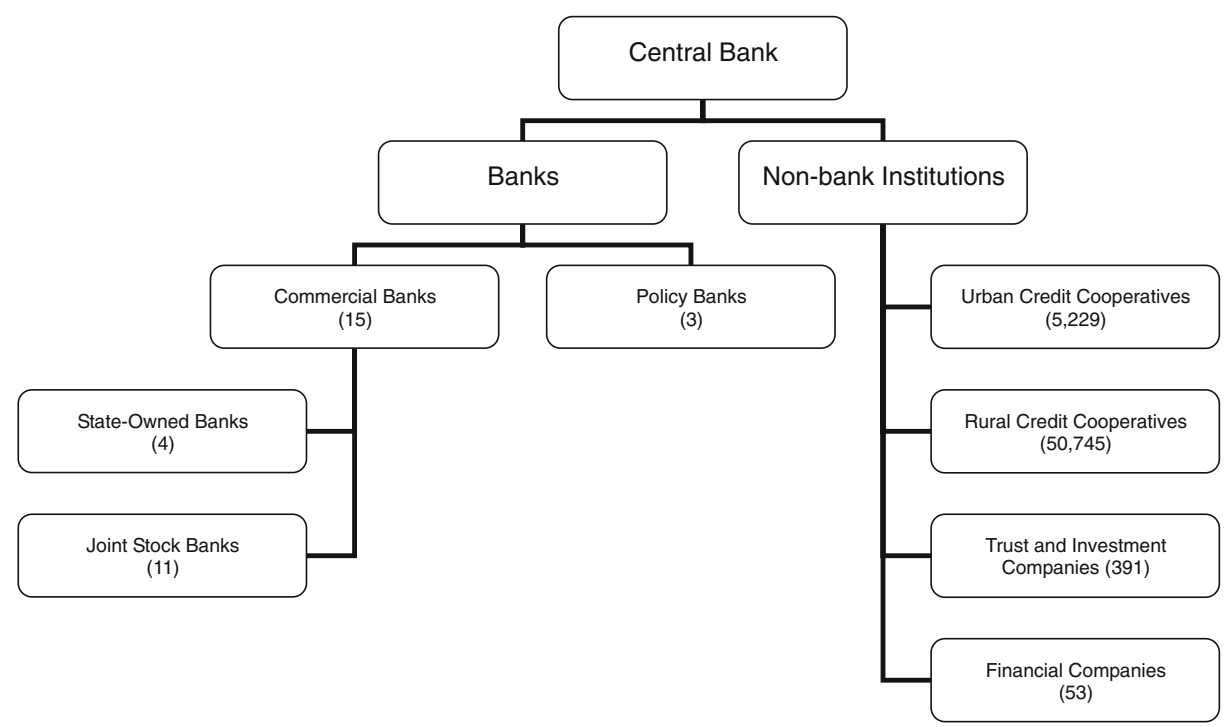

Source: Almanac of China's Finance and Banking (1995)

Fig. 1 Financial institutions in China at the end of 1994

coastal cities in 1994 and were allowed to conduct RMB business in Shanghai and Shenzhen two years later.

In contrast, the non-bank financial sector in China seems to be isolated and protected from competition by the Chinese government. RCCs obtained a monopoly in the rural financial market, after the Agricultural Bank of China left the market in 1996 (He (2006) and Xie (2001)). Similarly for the TICs as the Chinese government has put strict regulation on the entry into the trust market since 1994. Moreover, most of the TICs were closed down and merged in the late 1990s resulting in the remaining 30 TICs (Xie (1998) and Xin (2003)). ${ }^{9}$

Figure 2 presents the impact of market entry on the market shares of different financial institutions from 1994 to 2002, measured in \% of total assets. The four SOCBs cover around $78 \%$ of total assets. Due to competition, at the end of 2002 the SOCBs' market share declined towards $68 \%$. Joint stock banks gained market share towards $15 \%$. The market share of the foreign financial institutions had reached $1 \%$ at the end of 2002 . In the non-bank financial sector, the market share of RCCs was 7\%, which was comparable to that of TICs at the end of 1994. As the monopoly in the rural financial market, RCCs increased the market share from $7 \%$ to $11 \%$. The TICs' market share, however, decreased from $6 \%$ to $2 \%$.

\subsection{Liberalization}

China has since the mid-1990s gradually liberalized the interest rates in the interbank market. Meanwhile, the loan rates have been allowed to move within, gradually increasing,

\footnotetext{
${ }^{9}$ The bankruptcies of the China Agricultural Development Trust and Investment Company (CADTIC) and the Guangdong International Trust and Investment Company (GITIC) are examples in place.
} 
Table 1 Non-performing loans at bank and non-bank financial institutions

\begin{tabular}{|c|c|c|c|c|c|}
\hline \multicolumn{2}{|l|}{ Institutions } & \multicolumn{4}{|c|}{ Non-performing loan ratios ${ }^{a}$} \\
\hline \multirow[t]{6}{*}{ Banks } & Name & & & & \\
\hline & & 2000 & 2001 & 2002 & 2003 \\
\hline & $I C B C$ & 0.334 & 0.298 & 0.257 & 0.213 \\
\hline & $B O C$ & 0.272 & 0.275 & 0.225 & 0.181 \\
\hline & $C C B$ & 0.203 & 0.192 & 0.152 & 0.119 \\
\hline & $A B C$ & 0.468 & 0.421 & 0.381 & 0.321 \\
\hline
\end{tabular}

Non-bank Financial Rural Credit institutions Cooperatives
Average non-performing loan ratio was around 0.5 all over China by the end of 2003. In some underdeveloped provinces the ratio even reached $0.9^{\mathrm{b}}$.

The average non-performing loan ratio of 114 RCCs in western provinces was 0.5 by the end of 1997 , and increased to 0.56 by the end of $2002^{\mathrm{c}}$.

Trust and Investment Non-performing Loan ratio is unreported but expected to be Companies very high. The bankruptcy of Guangdong International Trust and Investment Company (GITIC) in 1998 is an example. The Chinese government often decides to close the financially bankrupt Trust and Investment Companies.

The total number of Trust and Investment companies shrank from 339 (by 1990) to 244 (by 1996) ${ }^{\mathrm{d}}$.

After the GITIC case in 1998, the Chinese government decided to further close bankrupted TICs and merge the survivals. The number of TICs shrank to $30^{\mathrm{e}}$.

\footnotetext{
a : Source: Sun (2004)

b : Source: Zhang (2003a, b)

c : Source: Wang and Li (2004)

d : Source: Xie (1998)

e : Source: Xin (2003)
}

"floating bounds" since the mid-1990s. RCCs only started to benefit from these floating bounds in late 1998. In 2004, the upper bound of the lending rate and the lower bound of the deposit rate of banks have been removed completely, which is not the case for the nonbank financial institutions.

\section{Empirical framework and data description}

\subsection{Empirical model}

To estimate the impact of financial development on economic growth, we start from a fixed effects panel model controlling for province and time fixed effects, following the traditional finance-growth literature such as King and Levine (1993b),

$$
G P Y_{i, t}=\alpha_{0} G D P_{i, t-1}+\alpha_{1} G K_{i, t}+\alpha F I_{i, t-1}+\alpha_{3} C O N_{i, t}+\sum_{i=1}^{I} \delta_{i} U_{i}+\sum_{t=1}^{T} \phi_{t} V_{t}+\varepsilon_{i, t}
$$




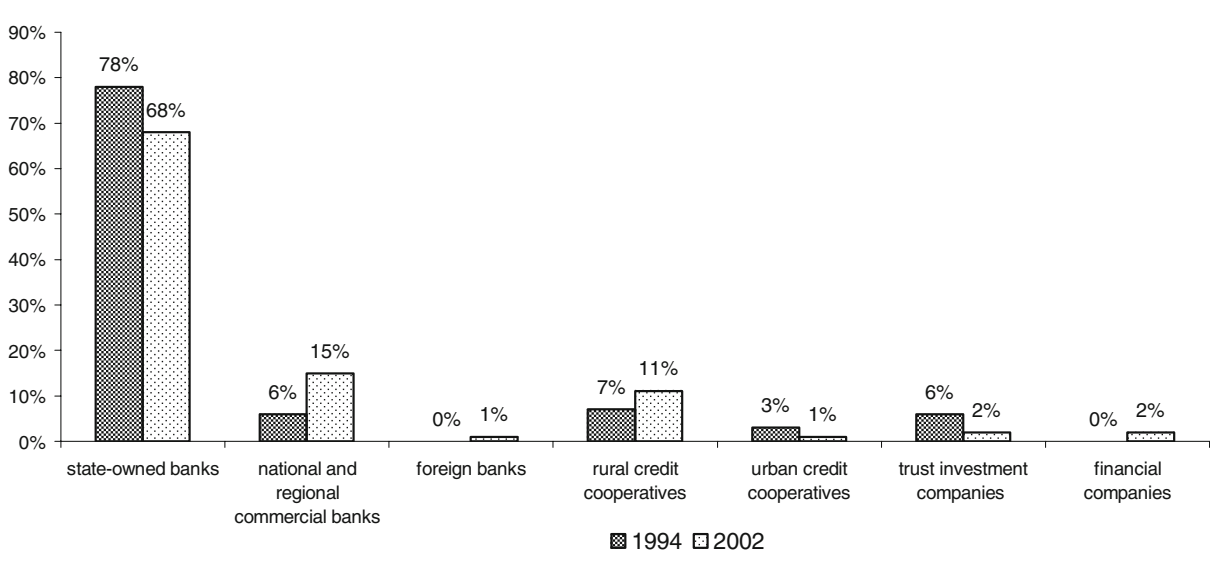

Source: Almanac of China's Finance and Banking $(1995,2003)$

Fig. 2 Market shares of financial institutions at the end of 1994 and 2002 (as \% of total assets)

where $G P Y_{i, t}$ is the growth rate of real per capita GDP at time $t$ and in province $i, G D P_{i, t-1}$ is the lagged real GDP per capita in province $i, G K_{i, t-1}$ is the lagged growth rate of real per capita capital stock in province $i$, and $F I_{i, t-1}$ is the lagged financial development indicator of either banks or non-bank financial institutions in province $i . U_{i}$ is a set of province dummy variables, $V_{t}$ is the set of time dummy variables, and $\delta_{i}$ and $\varphi_{i}$ are the vectors of coefficients. $C O N$ refers to the conditioning informational set. $C O N$ includes $F D I$ measured by the ratio of Foreign Direct Investment to GDP. Theory provides conflicting predictions regarding the impact of Foreign Direct Investment on growth. A positive effect is expected when FDI allows for the transfer of technological knowhow (see Romer (1993)). In contrast, Boyd and Smith (1992) argue that FDI may generate negative effects in an environment where there are existing distortions on the financial markets and labour markets (see also Guariglia and Poncet (2007)).

A central issue in the finance growth literature is potential reserve causality. We directly control for endogeneity between finance and growth by employing the system GMM estimator proposed by Arellano and Bover (1995). Regression (1) can be extended to a system of panel regressions as follows,

$$
\begin{array}{r}
G P Y_{i, t}=\beta_{0} G D P_{i, t-1}+\beta_{1} G K_{i, t}+\beta_{2} F I_{i, t-1}+\beta_{3} C O N_{i, t}+\sum_{i=1}^{I} \varphi_{i} U_{i}+\sum_{t=1}^{T} \gamma_{t} V_{t}+\varepsilon_{i, t} \\
\begin{aligned}
G P Y_{i, t}-G P Y_{i, t-1}=\beta_{0}\left(G D P_{i, t-1}-G D P_{i, t-2}\right) & +\beta_{1}\left(G K_{i, t}-G K_{i, t-1}\right)+\beta_{2}\left(F I_{i, t-1}-F I_{i, t-2}\right) \\
& +\beta_{3}\left(C O N_{i, t}-C O N_{i, t-1}\right)+\left(\varepsilon_{i, t}-\varepsilon_{i, t-1}\right)
\end{aligned}
\end{array}
$$

A system estimator jointly estimates the regression in levels (2) and the regression in differences (3). In order to correct for endogeneity, Arellano and Bover (1995) suggest employing lagged first differences of the explanatory variables as instruments for the equation in levels (2) and the lagged values of the explanatory variables in levels as instruments for the equation in differences (3). The crucial assumptions therefore are that 
the lagged differences of financial development are good instruments for explaining subsequent levels and the lagged levels of financial development are good instruments for explaining subsequent first differences. Rejection of the Sargan test of over-identifying restrictions at $5 \%$ level however questions the validity of those instruments. It is also necessary to test whether the error term of regression (3), $\varepsilon_{i, t}-\varepsilon_{i, t-1}$, is second-order serially autocorrelated. Accepting the null hypothesis of no second-order serial autocorrelation supports the assumption of the moment condition of (3).

\subsection{Financial development indicators}

We construct two financial development indicators at the province level for banks and nonbank financial institutions, respectively. Bank Deposit equals the ratio of the savings in the banking system to local GDP. Bank Deposit measures "financial depth" of the local banking sector. A second indicator is Bank Credit, which equals the credit extended by banks to local enterprises over local GDP. This indicator measures the financial resources provided by banks to provincial entities. In a similar fashion, we construct Non-bank Deposit, and Non-bank Credit for non-bank financial institutions.

\subsection{Data description}

Our dataset contains annual growth rates of real per capita GDP, real per capita capital stock, and FDI for 27 Chinese provinces over the period 1995-2003 ${ }^{10}$. Lagged financial development indicators, lagged real per capita GDP are also included in our dataset from 1994 to $2002^{11}$. Researchers use averaged data to avoid the inconsistence between calendar year (to calculate GDP) and fiscal year (to generate financial statement of financial institutions). For instance, Levine et al. (2000) use non-overlapping five-year average data in their GMM specifications. In the case of China, calendar year and fiscal year are the same. In addition, in our analysis there are only 9-year observations available. Therefore non-overlapping five-year average will greatly reduce the degree of freedom, or result in weak instruments (as only one lag available).

The financial development indicators in our study are calculated employing the statistics data reported by Almanac of China's Finance and Banking. The Almanac documents the provincial data of annual savings and loans of 5 banks: 4 state-owned banks and the Bank of Communications, the biggest bank of the national commercial banks. At the end of 1994, those 5 banks represent approximately $96 \%$ of the total assets of the banking sector.

We start our analysis in 1995 as Almanac of China's Finance and Banking reports the provincial data of savings and loans of rural credit cooperatives and of some selected trust and investment companies, financial companies, and other non-bank financial institutions only from 1994 onwards. ${ }^{12}$ Only the non-bank financial institutions that are considered to be large enough have their data included in the Almanac, whereas smaller institutions remain uncovered. This may introduce a reporting bias in that provinces with many small institutions may have an underestimated size of the non-banking sector. This potential reporting bias, however, should be controlled for by our province dummies in as far the reporting bias remains constant over our sample period within a province.

\footnotetext{
${ }^{10}$ Data reasons prevent us to include three provinces (Hubei, Tibet and Hainan).

11 The real capital stock per capita growth rate is calculated by perpetual inventory method (PIM).

12 The data of urban credit cooperatives are also reported but not for every year. We therefore decided to exclude urban credit cooperatives from our sample.
} 
Table 2 provides summary statistics. We present time averages for the 27 provinces. Table 2 highlights that there is substantial variation between provinces. The highest average annual real per capita GDP growth rate is $10.2 \%$ (Zhejiang province), while the lowest is $5.7 \%$ (Yunnan province). Shanghai, the richest province in China has on average annual real GDP per capita of 15,920 RMB while Yunnan, the poorest, has only 1,430 RMB. The financial development indicators for China are relatively high compared to those for other countries (see also Allen et al. (2005)). For example, the average ratios of Bank Deposit and Bank Credit across provinces are 0.843 and 0.683 , while the average ratios of Non-bank Deposit and Non-bank Credit across provinces are 0.141 and 0.109 only. Similarly, Beijing on average has the highest values of both Bank Deposit and Bank Credit, while Shandong province on average has the lowest levels of Bank Deposit and Bank Credit. Non-bank financial institutions exhibit the lowest development in Qinghai province, while Shanxi on average has the greatest Non-bank Deposit and Guangdong enjoys the greatest Non-bank Credit.

Table 3 provides correlations among the different financial development indicators and FDI. We find that the financial development indicators of the within bank and non-banking financial institutions are highly correlated. In particular, Bank Deposit is significantly positively correlated with Bank Credit (.84). Non-bank Deposit is significantly positively correlated with Non-bank Credit (.81). In general the bank and non-bank financial institution development indicators exhibit little pair wise correlation. FDI shows a significantly negative correlation with Bank Credit (-.19), and positive correlation with Non-bank Deposit (.31) and Non-bank Credit (.30).

Table 2 Summary statistics of growth and financial development indicators

\begin{tabular}{|c|c|c|c|c|c|}
\hline Variable & Obs & Mean & Std. Dev. & Min & Max \\
\hline Real GDP per capita growth rate & 27 & .077 & .013 & .057 & .102 \\
\hline Initial GDP (initial real GDP per capita) ${ }^{a}{ }^{b}$ & 27 & .471 & .313 & .143 & 1.592 \\
\hline $\begin{array}{l}\text { Per Capita Capital Stock Growth (real capital stock per } \\
\text { capita growth rate) }\end{array}$ & 27 & .114 & .020 & .072 & .145 \\
\hline Initial Aggregate GDP (initial real aggregate GDP) ${ }^{\text {a }}$ & 27 & 1854.933 & 1397.122 & 141.775 & 5353.567 \\
\hline $\begin{array}{l}\text { Aggregate Capital Stock Growth (real capital stock } \\
\text { aggregate growth rate) }\end{array}$ & 27 & .121 & .019 & .080 & .158 \\
\hline Bank Deposit (lagged ratio of bank savings to GDP) ${ }^{a}$ & 27 & .843 & .467 & .477 & 2.936 \\
\hline Bank Credit (lagged ratio of bank loans to GDP) ${ }^{a}$ & 27 & .683 & .224 & .402 & 1.223 \\
\hline $\begin{array}{l}\text { Non-bank Deposit (lagged ratio of savings at non-bank } \\
\text { financial institutions to GDP) }\end{array}$ & 27 & .141 & .053 & .049 & .268 \\
\hline $\begin{array}{l}\text { Non-bank Credit (lagged ratio of loans of non-bank } \\
\text { financial institutions to GDP) }^{\text {a }}\end{array}$ & 27 & .109 & .041 & .038 & .224 \\
\hline FDI (FDI to GDP) ${ }^{a}$ & 27 & .031 & .033 & .002 & .110 \\
\hline Road (number of kilometers of roads per square kilometer) & 27 & .292 & .188 & .027 & .761 \\
\hline $\begin{array}{l}\text { Railway (number of kilometers of railway per square } \\
\text { kilometer) }\end{array}$ & 27 & .027 & .052 & .002 & .270 \\
\hline
\end{tabular}

\footnotetext{
a : Logarithm in regression

b : Number in wan Yuan (10.000 RMB)

c : Number in yi Yuan (0.1 Billion RMB)
}

Almanac of China's Finance and Banking (1995-2003); China Statistics Yearbook (1996-2004) 
Table 3 Correlation matrix of financial development indictors and FDI. This table reports the correlation matrix of financial development indicators and FDI. Financial development indicators are in logarithm

\begin{tabular}{llllll}
\hline & Bank deposit & Bank credit & Non-bank deposit & Non-bank credit & FDI \\
\hline Bank deposit & 1.00 & & & \\
Bank credit & $.84^{* *}$ & 1.00 & & \\
Non-bank deposit & $.26^{* *}$ & .01 & 1.00 & 1.00 & $.36^{* *}$ \\
Non-bank credit & .10 & -.09 & $.81^{* *}$ & .00 \\
FDI & .03 & $-.19^{* *}$ & $.31^{* *}$ & \\
\hline
\end{tabular}

**stands for significance at $5 \%$ level

\section{The growth effects of financial development in China}

\subsection{Results}

Table 4 reports for different specifications the correlation of financial development on economic growth when using the fixed effects estimator, including FDI and Per Capita Capital Stock Growth as explanatory variables. The left panel (4(a) and 4(b)), displays the results including our bank financial development indicators in the regression. Bank Deposit (4(a)) is significantly positively correlated with future economic growth, so is Bank Credit (4(b)). The middle panel (4(c) and 4(d)) presents the results where non-bank financial development indicators enter the regression. Only Non-bank Deposit shows to be

Table 4 Finance and real per capita GDP growth: the Baseline Model, fixed effects estimators. Dependent variable: Real Per Capita GDP Growth

\begin{tabular}{|c|c|c|c|c|c|c|}
\hline & 4(a) & $4(b)$ & $4(c)$ & $4(d)$ & 4(e) & $4(f)$ \\
\hline Initial GDP Per Capita & $\begin{array}{l}-.339 * * \\
(.000)\end{array}$ & $\begin{array}{l}-.336^{* *} \\
(.000)\end{array}$ & $\begin{array}{l}-.345^{* *} \\
(.000)\end{array}$ & $\begin{array}{l}-.347 * * \\
(.000)\end{array}$ & $\begin{array}{l}-.338 * * \\
(.000)\end{array}$ & $\begin{array}{l}-.334 * * \\
(.000)\end{array}$ \\
\hline Per Capita Capital Stock Growth & $\begin{array}{l}.054 \\
(.272)\end{array}$ & $\begin{array}{l}.085 \\
(.091)\end{array}$ & $\begin{array}{l}.032 \\
(.505)\end{array}$ & $\begin{array}{l}.041 \\
(.427)\end{array}$ & $\begin{array}{l}.039 \\
(.419)\end{array}$ & $\begin{array}{l}.074 \\
(.146)\end{array}$ \\
\hline Bank Deposit & $\begin{array}{l}.066^{* *} \\
(.004)\end{array}$ & & & & $\begin{array}{l}.057 * \\
(.011)\end{array}$ & \\
\hline Bank Credit & & $\begin{array}{l}.078 * * \\
(.000)\end{array}$ & & & & $\begin{array}{l}.080 * * \\
(.000)\end{array}$ \\
\hline Non-bank Deposit & & & $\begin{array}{l}.032 * \\
(.026)\end{array}$ & & $\begin{array}{l}.026 \\
(.073)\end{array}$ & \\
\hline Non-bank Credit & & & & $\begin{array}{l}.008 \\
(.353)\end{array}$ & & $\begin{array}{l}.009 \\
(.229)\end{array}$ \\
\hline$F D I$ & $\begin{array}{l}.002 \\
(.598)\end{array}$ & $\begin{array}{l}.003 \\
(.563)\end{array}$ & $\begin{array}{l}.001 \\
(.745)\end{array}$ & $\begin{array}{l}.002 \\
(.666)\end{array}$ & $\begin{array}{l}.001 \\
(.762)\end{array}$ & $\begin{array}{l}.002 \\
(.723)\end{array}$ \\
\hline Provincial Dummies & yes & yes & yes & yes & yes & yes \\
\hline Yearly Dummies & yes & yes & yes & yes & yes & yes \\
\hline Obs & 243 & 243 & 243 & 243 & 243 & 243 \\
\hline R-squared & .504 & .513 & .497 & .483 & .514 & .516 \\
\hline
\end{tabular}

*indicates significance at 5\% level; and ** indicates significance at $1 \%$ level. $p$-value is reported between brackets 
significantly positively correlated with growth (4(c)). The right panel (4(e) and 4(f)) reports the results when both Bank Deposit (Credit) and Non-bank Deposit (Credit) are included into same specifications. Basically 4(e) and 4(f) confirm the previous results for our bank development indicators. Non-bank Deposit is now not statistically significant (4(e)), questioning the robustness of its correlation with growth.

Table 5 reports the results for the same specifications but excluding FDI and Per Capita Capital Stock Growth as control variables. FDI, as a control variable, does not have significant correlations with growth. In general the inclusion of FDI does not qualitatively alter our results on bank development, i.e. Bank Deposit, Bank Credit, and remains economically and statistically significant. Although Non-bank Deposit now becomes statistically significant in both specifications (5(c) and 5(e)), this correlation is less robust if we take into account the results from Table 4.

In Tables 4 and 5, Initial GDP Per Capita is significantly negative in all specifications. It captures the convergence effect of growth within the Chinese provinces. This effect has been documented in previous research dealing with China (see e.g. Boyreau-Debray (2003) and Démurger (2001)). Per Capita Capital Stock Growth is not statistically significant in most specifications of Table 4. This insignificance may stem from the fact that people move easier within a country (i.e. across provinces) than across countries. Hence an empirical application using local data of a country may suffer from the problem that the provincial population is quite unstable over time.

Table 6 reports for different specifications the impact of financial development on economic growth when using the system GMM estimator, including FDI and Per Capita Capital Stock Growth as explanatory variables. Among all financial development indicators, only the exogenous part of Bank Credit seems to have statistically positive impact on growth. Such impact is also economically significant. For example, as derived from 6(f), if Shandong, the province with the least bank credit would enjoy as much bank

Table 5 Finance and real per capita GDP growth: excluding Per Capita Capital Stock Growth and FDI, fixed effects estimators. Dependent variable: Real Per Capita GDP Growth

\begin{tabular}{lllllll}
\hline & $5(\mathrm{a})$ & $5(\mathrm{~b})$ & $5(\mathrm{c})$ & $5(\mathrm{~d})$ & $5(\mathrm{e})$ & $5(\mathrm{f})$ \\
\hline Initial GDP Per Capita & $-.334^{* *}$ & $-.329^{* *}$ & $-.342^{* *}$ & $-.343^{* *}$ & $-.334^{* *}$ & $-.327^{* *}$ \\
& $(.000)$ & $(.000)$ & $(.000)$ & $(.000)$ & $(.000)$ & $(.000)$ \\
Bank Deposit & $.065^{* *}$ & & & & $.056^{*}$ & \\
& $(.003)$ & & & & $(.011)$ & \\
Bank Credit & & $.070^{* *}$ & & & & $.074^{* *}$ \\
& & $(.001)$ & & & & $(.000)$ \\
Non-bank Deposit & & & $.034^{*}$ & & $.028^{*}$ & \\
& & & $(.014)$ & & $(.042)$ & \\
Non-bank Credit & & & & .010 & & .012 \\
& & & & $(.198)$ & & $(.089)$ \\
Provincial Dummies & yes & yes & yes & yes & yes & yes \\
Yearly Dummies & yes & yes & yes & yes & yes & yes \\
Obs & 243 & 243 & 243 & 243 & 243 & 243 \\
R-squared & .500 & .503 & .495 & .481 & .512 & .510 \\
\hline
\end{tabular}

*indicates significance at 5\% level; and ** indicates significance at $1 \%$ level. $p$-value is reported between brackets 
Table 6 Finance and real per capita GDP growth: the Baseline Model, System GMM estimators. Dependent variable: Real Per Capita GDP Growth

\begin{tabular}{|c|c|c|c|c|c|c|}
\hline & $6(a)$ & $6(b)$ & $6(c)$ & $6(d)$ & $6(e)$ & $6(f)$ \\
\hline Initial GDP Per Capita & $\begin{array}{l}-.289 * * \\
(.040)\end{array}$ & $\begin{array}{l}-.553 * * \\
(.003)\end{array}$ & $\begin{array}{l}-.532 * * \\
(.000)\end{array}$ & $\begin{array}{l}-.601 * * \\
(.000)\end{array}$ & $\begin{array}{l}-.223 * * \\
(.023)\end{array}$ & $\begin{array}{l}-.553^{* *} \\
(.000)\end{array}$ \\
\hline Per Capita Capital Stock Growth & $\begin{array}{l}-.180 \\
(.203)\end{array}$ & $\begin{array}{l}.366^{*} \\
(.035)\end{array}$ & $\begin{array}{l}-.116 \\
(.334)\end{array}$ & $\begin{array}{l}-.186 \\
(.131)\end{array}$ & $\begin{array}{l}-.103 \\
(.282)\end{array}$ & $\begin{array}{l}.099 \\
(.294)\end{array}$ \\
\hline Bank Deposit & $\begin{array}{l}-.126 \\
(.109)\end{array}$ & & & & $\begin{array}{l}.046 \\
(.199)\end{array}$ & \\
\hline Bank Credit & & $\begin{array}{l}.087 * \\
(.021)\end{array}$ & & & & $\begin{array}{l}.076^{* *} \\
(.007)\end{array}$ \\
\hline Non-bank Deposit & & & $\begin{array}{l}.023 \\
(.155)\end{array}$ & & $\begin{array}{l}-.002 \\
(.932)\end{array}$ & \\
\hline Non-bank Credit & & & & $\begin{array}{l}.002 \\
(.824)\end{array}$ & & $\begin{array}{l}.013 \\
(.321)\end{array}$ \\
\hline$F D I$ & $\begin{array}{l}.040 \\
(.189)\end{array}$ & $\begin{array}{l}-.006 \\
(.814)\end{array}$ & $\begin{array}{l}.008 \\
(.693)\end{array}$ & $\begin{array}{l}.014 \\
(.461)\end{array}$ & $\begin{array}{l}-.016 \\
(.222)\end{array}$ & $\begin{array}{l}-.005 \\
(.601)\end{array}$ \\
\hline Provincial Dummies & yes & yes & yes & yes & yes & yes \\
\hline Yearly Dummies & yes & yes & yes & yes & yes & yes \\
\hline Obs & 243 & 243 & 243 & 243 & 243 & 243 \\
\hline $\operatorname{AR}(2)$ Test & .808 & .949 & .966 & .965 & .933 & .811 \\
\hline Sargan Test & .143 & .198 & .071 & .181 & .122 & .124 \\
\hline
\end{tabular}

*indicates significance at 5\% level; and ** indicates significance at $1 \%$ level. $p$-value is reported between brackets

credit as Beijing, where the most bank credit is extended, ceteris paribus, Shandong's growth rate would increase approximately $8.5 \%$ per year, which is considerable. It would be better to use two-step GMM estimator as it is asymptotically more efficient. However our data cannot fit the two-step GMM as the covariance matrices do not converge. The Sargan test cannot be rejected at 5\% level for all specifications of Table 6, confirming the validity of instrumental variables.

We are further interested in the impact of foreign entry on the efficiency of bank institutions. We split the sample by whether there is any foreign financial institution existing in the province right after the commercialization of the SOCBs. It turns out that until 1995, there are 14 out 27 provinces in our sample witnessing the entry of foreign financial institutions.

Table 7 shows the results of two sub-samples, with and without foreign entry. We resort here to a fixed effects estimator due to the smaller sample size. ${ }^{13}$ The bank development in the provinces with foreign entry shows a more pronounced impact on future growth than those in the provinces without foreign entry. One may argue that foreign financial

\footnotetext{
${ }^{13}$ GMM estimators are generally consistent in large samples but likely to be biased in small samples (Hansen (1982)). This problem is more severe because we split the sample cross-sectionally whilst the system GMM estimator is designed for situations with panels that have few time periods and many individuals (Arellano and Bover (1995)). However, our results for the system GMM estimator are in line with those of the fixed effects estimator.
} 
Table 7 Bank finance and real per capita GDP growth: impact of the entry of foreign financial institutions, fixed effects estimators. Dependent variable: Real Per Capita GDP Growth

\begin{tabular}{|c|c|c|c|c|c|c|c|c|}
\hline & \multicolumn{4}{|c|}{ Sub-sample with foreign entry } & \multicolumn{4}{|c|}{ Sub-sample without foreign entry } \\
\hline & 7(a) & 7(b) & $7(\mathrm{c})$ & $7(\mathrm{~d})$ & $7(\mathrm{e})$ & $7(\mathrm{f})$ & $7(\mathrm{~g})$ & 7(h) \\
\hline Initial GDP Per Capita & $\begin{array}{l}-.291 * * \\
(.000)\end{array}$ & $\begin{array}{l}-.282^{* *} \\
(.000)\end{array}$ & $\begin{array}{l}-.288 * * \\
(.000)\end{array}$ & $\begin{array}{l}-.283 * * \\
(.000)\end{array}$ & $\begin{array}{l}-.357 * * \\
(.000)\end{array}$ & $\begin{array}{l}-.358 * * \\
(.000)\end{array}$ & $\begin{array}{l}-.367 * * \\
(.000)\end{array}$ & $\begin{array}{l}-.364 * * \\
(.000)\end{array}$ \\
\hline $\begin{array}{l}\text { Per Capita Capital Stock } \\
\text { Growth }\end{array}$ & & & $\begin{array}{l}-.033 \\
(.621)\end{array}$ & $\begin{array}{l}.003 \\
(.967)\end{array}$ & & & $\begin{array}{l}.101 \\
(.170)\end{array}$ & $\begin{array}{l}.110 \\
(.133)\end{array}$ \\
\hline Bank Deposit & $\begin{array}{l}.076^{*} \\
(.016)\end{array}$ & & $\begin{array}{l}.071^{*} \\
(.027)\end{array}$ & & $\begin{array}{l}.067^{*} \\
(.015)\end{array}$ & & $\begin{array}{l}.063^{*} \\
(.034)\end{array}$ & \\
\hline Bank Credit & & $\begin{array}{l}.102 * * \\
(.002)\end{array}$ & & $\begin{array}{l}.101 * * \\
(.007)\end{array}$ & & $\begin{array}{l}.071^{*} \\
(.045)\end{array}$ & & $\begin{array}{l}.072 \\
(.058)\end{array}$ \\
\hline$F D I$ & & & $\begin{array}{l}.010 \\
(.406)\end{array}$ & $\begin{array}{l}.001 \\
(.943)\end{array}$ & & & $\begin{array}{l}-.002 \\
(.733)\end{array}$ & $\begin{array}{l}-.000 \\
(.950)\end{array}$ \\
\hline Provincial Dummies & yes & yes & yes & yes & yes & yes & yes & yes \\
\hline Yearly Dummies & yes & yes & yes & yes & yes & yes & yes & yes \\
\hline Obs & 126 & 126 & 126 & 126 & 117 & 117 & 117 & 117 \\
\hline R-squared & .478 & .500 & .483 & .500 & .594 & .593 & .603 & .603 \\
\hline
\end{tabular}

*indicates significance at 5\% level; and ** indicates significance at $1 \%$ level. $p$-value is reported between brackets

institutions might choose to set up their branches where the economy was supposed to boom, and therefore, the sample split reflects the expectation to future growth. However, the average growth rates of the two sub-samples are almost the same. The provinces with foreign entry enjoy approximately a real GDP per capita growth rate of $7.8 \%$ per year while the others stay with a growth rate of $7.7 \%$ per year approximately. In addition, our regression includes provincial dummies, to avoid the criticism that our sample split might pick up regional effects, as foreign entry happened mostly in the coastal area. In sum, if indeed banks in the area with foreign entry foresaw that the potential competition from foreign banks was likely to threaten their market share and hence reacted by improving their competitiveness, it is plausible to conclude that the policy of opening-up improves the efficiency of those banks. Yet we should be very careful to draw the conclusion that only in provinces with foreign entry bank loans matter for growth, as regression 7(f) shows Bank Credit is still significantly positive at 5\% level in the sub-sample without foreign entry.

\subsection{Robustness}

In this subsection, we investigate the robustness of our results from both the fixed effects model and the system GMM panel model. We report the results of three additional tests; two of them focus on the fixed effects model while the third one relates to the system GMM panel model. First, Table 8 reports the fixed effects estimates of the impact of financial development on aggregate GDP growth rather than per capita GDP growth. The aggregate capital stock growth now becomes statistically significant and positive, which may be because within-country aggregate measures of capital stock growth suffer less from cross- 
Table 8 Finance and aggregate real GDP growth: the Baseline Model, fixed effects estimators. Dependent variable: Aggregate Real GDP Growth

\begin{tabular}{|c|c|c|c|c|c|c|}
\hline & $8(a)$ & $8(\mathrm{~b})$ & $8(c)$ & $8(d)$ & $8(e)$ & $8(f)$ \\
\hline Initial Aggregate GDP & $\begin{array}{l}-.255^{* *} \\
(.000)\end{array}$ & $\begin{array}{l}-.260 * * \\
(.002)\end{array}$ & $\begin{array}{l}-.268 * * \\
(.000)\end{array}$ & $\begin{array}{l}-.270 * * \\
(.000)\end{array}$ & $\begin{array}{l}-.258 * * \\
(.000)\end{array}$ & $\begin{array}{l}-.262^{* *} \\
(.000)\end{array}$ \\
\hline Aggregate Capital Stock Growth & $\begin{array}{l}.222 * \\
(.011)\end{array}$ & $\begin{array}{l}.271 * * \\
(.002)\end{array}$ & $\begin{array}{l}.240 * * \\
(.005)\end{array}$ & $\begin{array}{l}.252 * * \\
(.004)\end{array}$ & $\begin{array}{l}.234^{* *} \\
(.007)\end{array}$ & $\begin{array}{l}.283 * * \\
(.001)\end{array}$ \\
\hline Bank Deposit & $\begin{array}{l}.033^{*} \\
(.044)\end{array}$ & & & & $\begin{array}{l}.034 * \\
(.044)\end{array}$ & \\
\hline Bank Credit & & $\begin{array}{l}.057 * * \\
(.001)\end{array}$ & & & & $\begin{array}{l}.056^{* *} \\
(.001)\end{array}$ \\
\hline Non-bank Deposit & & & $\begin{array}{l}-.002 \\
(.857)\end{array}$ & & $\begin{array}{l}-.005 \\
(.666)\end{array}$ & \\
\hline Non-bank Credit & & & & $\begin{array}{l}-.005 \\
(.464)\end{array}$ & & $\begin{array}{l}-.004 \\
(.590)\end{array}$ \\
\hline FDI & $\begin{array}{l}-.001 \\
(.892)\end{array}$ & $\begin{array}{l}-.001 \\
(.816)\end{array}$ & $\begin{array}{l}-.001 \\
(.885)\end{array}$ & $\begin{array}{l}-.001 \\
(.932)\end{array}$ & $\begin{array}{l}-.001 \\
(.899)\end{array}$ & $\begin{array}{l}-.001 \\
(.851)\end{array}$ \\
\hline Provincial Dummies & yes & yes & yes & yes & yes & yes \\
\hline Yearly Dummies & yes & yes & yes & yes & yes & yes \\
\hline Obs & 243 & 243 & 243 & 243 & 243 & 243 \\
\hline R-squared & .536 & .553 & .528 & .530 & .537 & .554 \\
\hline
\end{tabular}

*indicates significance at 5\% level; and ** indicates significance at $1 \%$ level. $p$-value is reported between brackets

province labor mobility, compared to measures at per-capita level. More importantly, in Table 8, the main results of the impact of finance on growth remain robust.

A second robustness test investigates whether the fixed effects estimates suffer from omitted variable problems. For instance, Démurger (2001) suggests local infrastructure may matter for growth in China. Following Démurger (2001), we introduce into the specification Road, which measures the number of kilometers of roads per square kilometer in a particular province (lagged with one year), and its square $\operatorname{Road}^{2}$, as well as Railway, which measures the number of kilometers of railway per square kilometer in a particular province (lagged with one year), and Railway ${ }^{2}$. As Table 9 shows, after controlling for variables capturing local infrastructure, our results remain robust.

Finally, if GDP growth rate is auto-correlated, the system GMM model may be misspecified. In Table 10, we include lagged Real Per Capita GDP Growth into the specification and estimate a dynamic system GMM model. As shown in Table 10, the coefficient of Lagged Real Per Capita GDP Growth is statistically not different from zero. Table 10 also shows that our main results remain robust, whilst the validity of instrumental variables is confirmed by no rejection of the Sargan test at $5 \%$ level.

\section{Discussion}

How to reconcile these results with Allen et al. (2005), who argue that the Chinese financial system is weak and that informal finance and informal institutions promote 
Table 9 Finance and real per capita GDP growth: the Baseline Model with extra controlling variables, fixed effects estimators. Dependent variable: Real Per Capita GDP Growth

\begin{tabular}{|c|c|c|c|c|c|c|}
\hline & 9(a) & 9(b) & $9(\mathrm{c})$ & $9(\mathrm{~d})$ & $9(\mathrm{e})$ & $9(\mathrm{f})$ \\
\hline Initial GDP Per Capita & $\begin{array}{l}-.350^{* *} \\
(.000)\end{array}$ & $\begin{array}{l}-.349 * * \\
(.000)\end{array}$ & $\begin{array}{l}-.356^{* *} \\
(.000)\end{array}$ & $\begin{array}{l}-.358^{* *} \\
(.000)\end{array}$ & $\begin{array}{l}-.346^{* *} \\
(.000)\end{array}$ & $\begin{array}{l}-.345^{* *} \\
(.000)\end{array}$ \\
\hline Per Capita Capital Stock Growth & $\begin{array}{l}.056 \\
(.260)\end{array}$ & $\begin{array}{l}.085 \\
(.090)\end{array}$ & $\begin{array}{l}.030 \\
(.546)\end{array}$ & $\begin{array}{l}.034 \\
(.513)\end{array}$ & $\begin{array}{l}.045 \\
(.347)\end{array}$ & $\begin{array}{l}.077 \\
(.118)\end{array}$ \\
\hline Bank Deposit & $\begin{array}{l}.069^{* *} \\
(.005)\end{array}$ & & & & $\begin{array}{l}.063^{*} \\
(.012)\end{array}$ & \\
\hline Bank Credit & & $\begin{array}{l}.086^{* *} \\
(.000)\end{array}$ & & & & $\begin{array}{l}.089 * * \\
(.000)\end{array}$ \\
\hline Non-bank Deposit & & & $\begin{array}{l}.033^{*} \\
(.044)\end{array}$ & & $\begin{array}{l}.028 \\
(.083)\end{array}$ & \\
\hline Non-bank Credit & & & & $\begin{array}{l}.008 \\
(.386)\end{array}$ & & $\begin{array}{l}.011 \\
(.205)\end{array}$ \\
\hline$F D I$ & $\begin{array}{l}.003 \\
(.485)\end{array}$ & $\begin{array}{l}.004 \\
(.444)\end{array}$ & $\begin{array}{l}.002 \\
(.615)\end{array}$ & $\begin{array}{l}.003 \\
(.558)\end{array}$ & $\begin{array}{l}.002 \\
(.635)\end{array}$ & $\begin{array}{l}.002 \\
(.607)\end{array}$ \\
\hline Road & $\begin{array}{l}-.077 \\
(.511)\end{array}$ & $\begin{array}{l}-.081 \\
(.480)\end{array}$ & $\begin{array}{l}-.130 \\
(.291)\end{array}$ & $\begin{array}{l}-.107 \\
(.392)\end{array}$ & $\begin{array}{l}-.113 \\
(.346)\end{array}$ & $\begin{array}{l}-.107 \\
(.361)\end{array}$ \\
\hline $\operatorname{Road}^{2}$ & $\begin{array}{l}.019 \\
(.834)\end{array}$ & $\begin{array}{l}.003 \\
(.977)\end{array}$ & $\begin{array}{l}.049 \\
(.624)\end{array}$ & $\begin{array}{l}.019 \\
(.850)\end{array}$ & $\begin{array}{l}.060 \\
(.544)\end{array}$ & $\begin{array}{l}.031 \\
(.744)\end{array}$ \\
\hline Railway & $\begin{array}{l}-.565 \\
(.341)\end{array}$ & $\begin{array}{l}-.599 \\
(.304)\end{array}$ & $\begin{array}{l}-.349 \\
(.589)\end{array}$ & $\begin{array}{l}-.550 \\
(.375)\end{array}$ & $\begin{array}{l}-.351 \\
(.582)\end{array}$ & $\begin{array}{l}-.521 \\
(.389)\end{array}$ \\
\hline Railway $^{2}$ & $\begin{array}{l}.803 \\
(.554)\end{array}$ & $\begin{array}{l}.790 \\
(.555)\end{array}$ & $\begin{array}{l}.331 \\
(.822)\end{array}$ & $\begin{array}{l}.792 \\
(.577)\end{array}$ & $\begin{array}{l}.316 \\
(.828)\end{array}$ & $\begin{array}{l}.607 \\
(.661)\end{array}$ \\
\hline Provincial Dummies & yes & yes & yes & yes & yes & yes \\
\hline Yearly Dummies & yes & yes & yes & yes & yes & yes \\
\hline Obs & 243 & 243 & 243 & 243 & 243 & 243 \\
\hline R-squared & .522 & .536 & .514 & .500 & .532 & .540 \\
\hline
\end{tabular}

*indicates significance at $5 \%$ level; and $* *$ indicates significance at $1 \%$ level. $p$-value is reported between brackets

growth, and Ayyagari et al. (2007), (Demitriades et al. 2008), and Rousseau and Xiao (2007), who find that formal finance leads to greater firm growth? We find that only banking development leads to greater growth, in line with some of the findings of Ayyagari et al. (2007), (Demitriades et al. 2008), and Rousseau and Xiao (2007), whereas the development of non-bank financial institutions seems not to cause growth. It is clear that the Chinese financial institutions do have inefficiencies compared to their international counterparts. But compared to other domestic financial institutions, the Chinese banks have benefited greatly from financial reforms and thus changed dramatically from only granting policy loans to starting allocating capital and monitoring projects according to commercial standards.

Except for why banks may perform better as we discussed in the second section, there are some other reasons we think should not be ignored. First, banks may enjoy a better pool of borrowers. Borrowers may prefer to borrow from banks because bank loans, 
especially short-term loans, are less costly than other financial instruments. Among those candidates, banks typically pick up the larger firms with collateral (see e.g. two surveys of firms' financing patterns in China carried out by PBOC) ${ }^{14}$. This explains why banks increased their relative exposure towards the financing of private firms, even though most financed private firms were large ones. In this spirit, "chasing the winners" is a good strategy for Chinese banks. Second, financing the state-owned sector per se doesn't imply directly misallocating of capital. We notice that the state-owned sector still contributed around $40 \%$ of GDP growth in recent years (Sun (2004)). As banks can to some extent screen good borrowers from bad and allocate the capital to profitable state-owned enterprises (Cull and Xu (2000)), bank loans are still very important in supporting local industrial growth. Last, banks with many branches all around the country made it easier to share the credit records of clients and benefit from greater industry expertise than their standing alone counterparts.

\section{Concluding remarks}

This paper contributes to the recent debate on the role of formal and informal finance for growth in China using some new perspectives. In particular, we argue that non-bank financial institutions in China have characteristics of both informal and formal finance and deserve special attention. Therefore comparison of the heterogeneity between those two types of financial institutions allows gaining further insights on whether the formal or the informal financial sector leads to growth in China. Non-bank financial institutions, which have long been ignored by the finance and growth literature, are thus brought under the spot for the first time. In addition, we are the first to link financial reforms, financial development and growth. Banks and non-bank financial institutions thus serve as the "reference group" for each other in identifying the reform-finance-growth nexus.

Using a province-level panel dataset over the period 1995-2003, we find that bank development, in particular bank credit, greatly contributes to province growth. For instance, an increase of bank loans to GDP ratio from the lowest to the highest in our sample increases future annual growth by 8.5 percentage points. In contrast, in most specifications, the development of non-bank financial institutions is not correlated with growth. We attribute this difference to banks having benefited more from the reform process such as commercialization, entry deregulation and liberalization than non-bank financial institutions. Banks may have been able to gradually build up a commercial culture, getting rid of

\footnotetext{
${ }^{14}$ A survey carried out by People's Bank of China in October, 2002, shows that $47.7 \%$ of the total bank loans had been extended to the non-state-owned sector during the first 9 months in 2002 . This survey covers 184 cities from 30 provinces of China, 10,804 non-state-owned enterprises and 2,633 banks (branches) and non-bank financial institutions. The satisfaction ratio varies among different types of applicants. For example, the satisfaction ratio of large non-state-owned enterprises is $85 \%$ while that of small and medium non-state-owned enterprises is only 69.5\%. Another survey carried out by People's Bank of China in 2002 shows that after the deregulation of interest rate discrimination, bank loans become the most important sources for SMEs in Weizhou city, whose economic growth is typically driven by the private sector. his survey covers 190 SMEs and 13 banks and credit cooperatives in Wenzhou. The satisfaction ratio still varies between small and medium sized enterprises. For example, the satisfaction ratio of loans reported by medium sized enterprises is $72.7 \%$ while that reported by small sized enterprises is only $60.5 \%$. Source: Almanac of China's Finance and Banking (2003)
} 
Table 10 Finance and real per capita GDP growth: the Baseline Model, Dynamic System GMM estimators. Dependent variable: Real Per Capita GDP Growth

\begin{tabular}{lllllll}
\hline & $10(\mathrm{a})$ & $10(\mathrm{~b})$ & $10(\mathrm{c})$ & $10(\mathrm{~d})$ & $10(\mathrm{e})$ & $10(\mathrm{f})$ \\
\hline Lagged Real Per Capita GDP Growth & -.323 & -.068 & .174 & .078 & .178 & -.079 \\
& $(.147)$ & $(.609)$ & $(.237)$ & $(.624)$ & $(.231)$ & $(.564)$ \\
Initial GDP Per Capita & $-.559^{*}$ & $-.580^{* *}$ & $-.579^{* *}$ & $-.590^{* *}$ & $-.588^{* *}$ & $-.571^{* *}$ \\
& $(.046)$ & $(.007)$ & $(.000)$ & $(.001)$ & $(.000)$ & $(.008)$ \\
Per Capita Capital Stock Growth & -.089 & $.375^{*}$ & -.102 & -.204 & -.115 & $.358^{*}$ \\
& $(.771)$ & $(.029)$ & $(.451)$ & $(.115)$ & $(.407)$ & $(.049)$ \\
Bank Deposit & -.416 & & & & .048 & \\
& $(.089)$ & & & & $(.542)$ & \\
Bank Credit & & $.085^{*}$ & & & & $.085^{*}$ \\
& & $(.028)$ & & & & $(.025)$ \\
Non-bank Deposit & & & .015 & & .010 & \\
Non-bank Credit & & & $(.438)$ & & $(.652)$ & \\
FDI & & & & .004 & & .010 \\
& & & & $(.632)$ & & $(.784)$ \\
Provincial Dummies & .117 & .000 & .025 & .024 & .030 & -.000 \\
Yearly Dummies & $(.180)$ & $(.991)$ & $(.244)$ & $(.245)$ & $(.194)$ & $(.997)$ \\
Obs & yes & yes & yes & yes & yes & yes \\
AR(2) Test & yes & yes & yes & yes & yes & yes \\
Sargan Test & 216 & 216 & 216 & 216 & 216 & 216 \\
& .258 & .455 & .547 & .912 & .534 & .456 \\
& .334 & .085 & .143 & .101 & .118 & .050 \\
\hline
\end{tabular}

*indicates significance at $5 \%$ level; and $* *$ indicates significance at $1 \%$ level. $p$-value is reported between brackets

the intervention from the local government, attract better quality personnel, and improve their viability during opening-up for foreign institutions. Compared to banks, non-bank financial institutions were largely underdeveloped. This argument is also confirmed by China's recent attempts to reform urban and rural credit cooperatives by transforming them into local commercial banks. The different findings on the development of banks and nonbank financial institutions show that the reform-finance-growth nexus also applies within the formal financial sector in China.

Acknowledgements The authors thank Stijn Claessens (the Editor), Paul De Grauwe, Belton M. Fleisher, Joseph P.H. Fan, Iftekhar Hasan, Joep Konings, Iikka Korhonen, Alfred Lehar, Steven Ongena, Gérard Roland, Lijan Sun, Ellen Vanassche, Patrick Van Cayseele, Vincenzo Verardi, Xiaobo Zhang, an anonymous referee, as well as seminar participants of the LICOS-Monetary Economics workshop in Leuven, the K.U. Leuven-Peking University Workshop in Beijing, the BOFIT seminar at the Bank of Finland in Helsinki, the Fudan University financial economics workshop in Shanghai, the "Debt, money and finance in integrated global markets" conference in Rome, and the second Financial Intermediation Research Society conference in Shanghai for useful comments. Financial assistance from FWO-Flanders, NWO-The Netherlands, and the Research Council of the University of Leuven is gratefully acknowledged. Hans Degryse holds the TILECAFM Chair on Financial Market Regulation and is a CESIfo research fellow. 
Open Access This article is distributed under the terms of the Creative Commons Attribution Noncommercial License which permits any noncommercial use, distribution, and reproduction in any medium, provided the original author(s) and source are credited.

\section{References}

Acemoglu D, Zilibotti F (1997) Was Prometheus Unbound by Chance? Risk, Diversification, and Growth. J Polit Econ 105:709-775

Allen F, Qian J, Qian M (2005) Law, Finance and Economic Growth in China. J Financ Econ 77:57-116

Arellano M, Bover O (1995) Another Look at the Instrumental-Variable Estimation of Error-Components Models. J Econom 68:29-52

Ayyagari M, Demirgüç-Kunt A, Maksimovic V (2007) Formal versus Informal Finance: Evidence from China. World Bank Policy Research Working Paper Series.

Boyd JH, Smith BD (1992) Intermediation and the Equilibrium Allocation of Investment Capital: Implications for Economic Development. J Monet Econ 30:409-432

Boyreau-Debray G (2003) Financial Intermediation and Growth: Chinese Style. World Bank Policy Research Working Paper, 3027.

Cull R, Xu LC (2000) Bureaucrats, State Banks, and the Efficiency of Credit Allocation: The Experience of Chinese State-Owned Enterprises. J Comp Econ 28:1-31

Demirgüç-Kunt A, Maksimovic V (1998) Law, Finance and Firm Growth. J finance 53:2107-2137

Demitriades PO, Du J, Girma S, Xu S (2008) Does the Chinese Banking System Promote the Growth of Firms?, University of Leicester Discussion Paper 08/6.

Démurger S (2001) Infrastructure Development and Economic Growth: An Explanation for Regional Disparities in China? J Comp Econ 29:95-117

Greenwood J, Jovanovic B (1990) Financial Development, Growth, and the Distribution of Income. J Polit Econ 98:1076-1107

Guariglia A, Poncet S (2007) Could financial distortions be no impediment to economic growth after all? Evidence from China, forthcoming in Journal of Comparative Economics.

Guiso L, Sapienza P, Zingales L (2004) Does local financial development matter? Q J Econ 119(3):929-969

Haber SH (1991) Industrial Concentration and the Capital Markets: A Comparative Study of Brazil, Mexico, and the United States, 1830-1930. J Econ Hist 51:559-580

Haber SH (1997) Financial Markets and Industrial Development: A Comparative Study of Governmental Regulation, Financial Innovation and Industrial Structure in Brazil and Mexico, 1840-1940. In: Haber SH (ed) How Latin America Fell Behind? CA, Stanford University Press, Stanford, pp 146-178

Hansen L (1982) Large sample properties of generalized method of moments estimators. Econometrica 50 (3):1029-54

Hasan I, Wachtel P, Zhou M (2006) Institutional Development, Financial Deepening and Economic Growth: Evidence from China. BOFIT Discussion Paper No. 12/2006.

He G (2006) Chuantong Nongqu Nongcun Xinyongshe Gaige yu Chuangxin (Reforms and Innovation of Rural Credit Cooperatives in Traditional Rural Region). Working paper of Center of Rural Finance and Investment Studies. http:/www.cngdsz.net/discourse/article_show.asp?typeid=2\&articleid=5656

Jayaratne J, Strahan PE (1996) The Finance-Growth Nexus: Evidence from Bank Branch Deregulation. Q J Econ 111:639-670

King RG, Levine R (1993a) Finance and Growth: Schumpeter Might Be Right. Q J Econ 108:717-738

King RG, Levine R (1993b) Finance, Enterpreneurship and Growth: Theory and Growth. J Monet Econ 32:513-542

Kumar A, Lardy N, Albrecht W, Chuppe T, Selwyn S, Perttunen P, Zhang T (1997) China's Non-Bank Financial Institutions. Trust and Investment Companies, World Bank Discussion Paper 358

La Porta R, Lopez-de-Silanes F, Shleifer A, Vishny RW (1998) Law and Finance. J Polit Econ 106:1113-1150

Laurenceson J, Chai JCH (2003) Financial Reform and Economic Development, in Advances in Chinese Economic Studies, Edward Elgar.

Levine R (2004) Finance and Growth: Theory and Evidence, NBER Working Papers, 10766.

Levine R, Loayza N, Beck T (2000) Financial Intermediation and Growth: Causality and Causes. J Monet Econ 46:31-77

Levine R, Zervos S (1998) Stock Markets, Banks, and Economic Growth. Am Econ Rev 88:537-558

Li R (2001) Revisit to China's Financial Reform. EMEAP Review, Nov, 2001 Edition.

Li K, Liu T (2001) Impact of Liberalization of Financial Resources in China's Economic Growth: Evidences from Provinces. J Asian Econ 12:245-262

Romer P (1993) Idea gaps and object gaps in economic development. J Monet Econ 3:543-573 
Rousseau PL, Xiao S (2007) Banks, Stock Markets and China's Great Leap Forward. Emerging Markets Review 8:206-217

Sun L (2004) Zhongguo Jingrong Tixi de Cuiruo Xing (The Fragility in China's Financial Systems). The Study of Finance and Economics 2004(1):61-69

Wang S, Li Y (2004) Zhongguo Xibu Diqu Nongcun Xinyongshe de Zhili Jiegou, Xingwei yu Yeji (Managerial Structure, Conduct and Performance of Rural Credit Cooperatives in Western China). Issues in Agricultural Economy 2004(6):38-42

Xie Ping (1998) Zhongguo Fei Yinhang Jinrong Jigou Yanjiu ( A Study of the Chinese Non-bank Financial Institutions), Journal of Economics and Finance 1998 (3), 3-7, (4), 3-6, (5), 3-7.

Xie P (2001) Zhongguo Nongcun Xinyongshe Tizhi Gaige de Zhenglun (the Debate on the Reform of China's Rural Credit Cooperatives System). Journal of Financial Research 2001(1):1-13

Xin M (2003) Xintuo Hangye Fazhan ji Jingzheng Shitai Fenxi (An Analysis of the Development of and the Competition in China's Trust Industry). Report for Development and Research Center of the State Council of P. R. China

Xu M (2005) Resolution of Non-Performing Loans in China. Glucksman Fellowship Program Student Research Reports 2005. http://w4.stern.nyu.edu/glucksman/research.cfm?doc id=1519

Zhang Q (2003a) Zhongguo Nongcun Jinrong Xianzhang yu Zhengce Fengxi (Analysis of Current Issues and Policies of the Chinese Rural Financial System). In: China Center for Economic Research Working Paper Series 2003. China Center for Economic Research, Peking University, Beijing.

Zhang X (2003b) Guanyu Guoyou Yinhang Buliang Daikuan de Jige Wenti (Issues of the NPLs of the Stateowned Banks). China Economic Times, April, 2nd, 2003. 